\title{
Evaluation Of Next Generation Nuclear Power Plant (NGNP) Intermediate Heat Exchanger (IHX) Operation Conditions
}

\author{
E. A. Harvego
}

April 2006

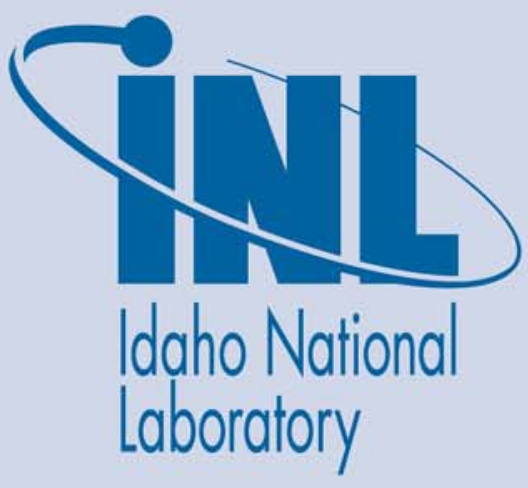

The INL is a U.S. Department of Energy National Laboratory operated by Battelle Energy Alliance 



\title{
EVALUATION OF NEXT GENERATION NUCLEAR POWER PLANT (NGNP) INTERMEDIATE HEAT EXCHANGER (IHX) OPERATING CONDITIONS
}

\author{
E. A. Harvego
}

April 2006

Idaho National Laboratory

Idaho Falls, Idaho 83415

Prepared for the

U.S. Department of Energy

Assistant Secretary for Nuclear Energy

Under DOE Idaho Operations Office

Contract DE-AC07-05ID14517 


\begin{abstract}
This report summarizes results of a preliminary evaluation to determine the operating conditions for the Next Generation Nuclear Plant (NGNP) Intermediate Heat Exchanger (IHX) that will transfer heat from the reactor primary system to the demonstration hydrogen production plant(s). The Department of Energy is currently investigating two primary options for the production of hydrogen using a high temperature reactor as the power source. These options are the High Temperature Electrolysis (HTE) and Sulfur-Iodine (SI) thermochemical hydrogen production processes. However, since the SI process relies entirely on process heat from the reactor, while the HTE process relies primarily on electrical energy with only a small amount of process heat required, the design of the IHX is dictated by the SI process heat requirements. Therefore, the IHX operating conditions were defined assuming $50 \mathrm{MWt}$ is available for the production of hydrogen using the SI process.

Three configurations for the intermediate loop were evaluated, including configurations for both direct and indirect power conversion systems. The HYSYS process analysis software was used to perform sensitivity studies to determine the influence of reactor outlet temperatures, intermediate loop working fluids (helium and molten salt), intermediate loop pressures, and intermediate loop piping lengths on NGNP performance and IHX operating conditions. The evaluation of NGNP performance included assessments of overall electric power conversion efficiency and estimated hydrogen production efficiency. Based on these evaluations, recommended IHX operating conditions are defined.
\end{abstract}




\section{TABLE OF CONTENTS}

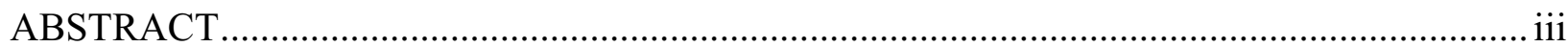

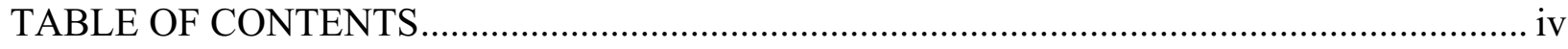

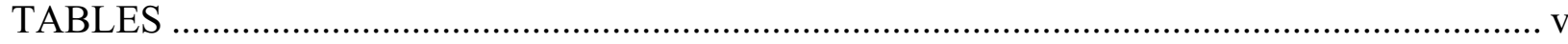

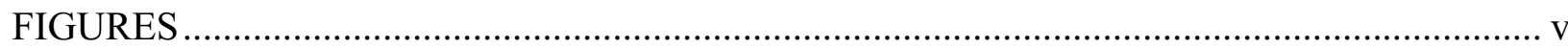

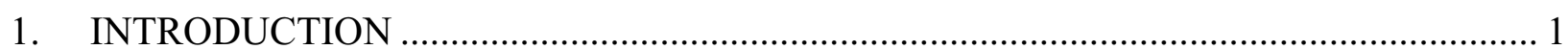

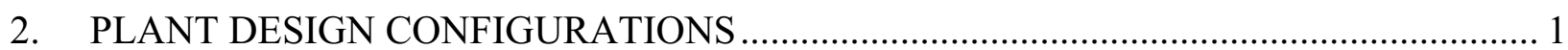

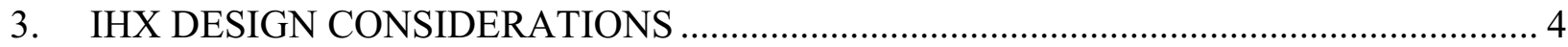

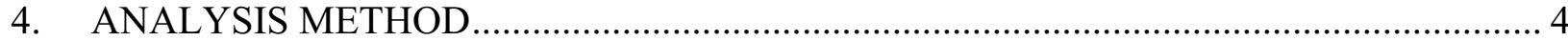

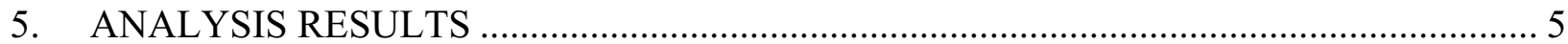

5.1 Configuration 1 (direct electrical cycle and a parallel IHX).................................... 6

5.2 Configuration 2 (direct electrical cycle, parallel IHX, and SHX) ............................. 12

5.3 Configuration 3 (indirect electrical cycle and a parallel SHX) ............................... 13

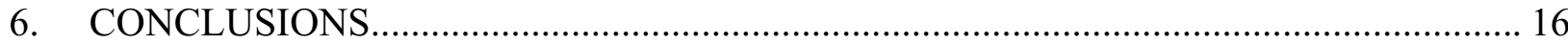

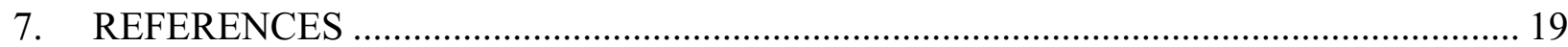




\section{TABLES}

Table 1. HYSYS results for Configuration 1 with reactor outlet temperatures of $850{ }^{\circ} \mathrm{C}, 900{ }^{\circ} \mathrm{C}$ and $950{ }^{\circ} \mathrm{C}$. 7

Table 2. System conditions as a function of reactor outlet temperature for Configuration 1....... 8

Table 3. HYSYS results for Configuration 1 with variable intermediate loop heat losses. ......... 8

Table 4. HYSYS results for Configuration 1 with variable intermediate loop pressures........... 10

Table 5. HYSYS calculated system conditions for variable intermediate loop pressure and working fluid

Table 6. HYSYS results for Configuration 2 with variable reactor outlet temperature. 11

Table 7. HYSYS results for Configuration 3 with variable reactor outlet temperature. 13

Table 8. System conditions for Configuration 3 with variable reactor outlet temperature 14

Table 9. Recommended IHX thermal-hydraulic conditions for Configuration 1.................... 17

Table 10. Recommended thermal-hydraulic conditions for Configuration 3.......................... 18

\section{FIGURES}

Figure 1. Configuration 1 (direct electrical cycle and a parallel IHX) .................................. 2

Figure 2. Configuration 2 (direct electrical cycle, parallel IHX, and SHX) ............................. 3

Figure 3. Configuration 3 (indirect electrical cycle and a parallel SHX)................................ 3

Figure 4. HYSYS model of Configuration 1 (direct electical cycle and a parallel IHX) ........... 6

Figure 5. HYSYS model of Configuration 1 with Flinak as intermediate loop working fluid.... 11

Figure 6. HYSYS model of Configuration 2 (direct electrical cycle, parallel IHX, and SHX). . 12

Figure 7. HYSYS model of Configuration 3 (indirect electrical cycle and a parallel SHX)...... 14 


\section{INTRODUCTION}

This report summarizes results of a preliminary evaluation to determine the operating conditions for the Next Generation Nuclear Plant (NGNP) Intermediate Heat Exchanger (IHX) that will transfer heat from the reactor primary system to the demonstration hydrogen production plant(s). The Department of Energy is currently investigating two primary options for the production of hydrogen using a high temperature reactor as the power source. These options are the High Temperature Electrolysis (HTE) and Sulfur-Iodine (SI) thermochemical production processes. However, since the SI process relies entirely on process heat from the reactor, while the HTE process relies primarily on electrical energy with only a small amount of process heat required, the design of the IHX is dictated by the SI process heat requirements. Therefore, the IHX operating conditions are defined assuming $50 \mathrm{MWt}$ is available for the production of hydrogen using the SI process. This heat is delivered to the hydrogen production process through an intermediate heat transport loop and possibly a tertiary loop to provide adequate separation between the reactor primary system and the hydrogen production process. This separation is needed to minimize the potential for tritium migration between the reactor primary system and hydrogen production process, and to ensure that accident or upset conditions in the hydrogen production facility do not propagate to or impact the operation of the NGNP reactor.

Depending on the NGNP design (either a direct or indirect power conversion cycle), the IHX will be required to provide heat for hydrogen production or for both hydrogen production and power conversion. Therefore, several different plant configurations, which included both direct and indirect power conversion cycles, were evaluated and three configurations were selected for further assessments.

The following section defines the basis for the plant configurations selected for further analyses leading to the definition of IHX operating conditions.

\section{PLANT DESIGN CONFIGURATIONS}

Several different potential plant design configurations for the NGNP with either direct or indirect power conversion cycles and integrated IHX designs were proposed and evaluated by Davis et al., 2005. These configurations included IHX designs in parallel or series with the NGNP power conversion system. In the serial designs, the total primary system flow from the reactor outlet passes through the IHX where approximately $50 \mathrm{MWt}$ is transferred to the intermediate loop to drive the hydrogen production process. In these designs, heat is extracted from the primary fluid at the highest possible temperature (the reactor outlet temperature) for delivery to the hydrogen production process, while the power conversion system receives a slightly lower temperature fluid. In the parallel designs, the flow from the reactor outlet is split, with a small fraction of the flow (approximately $10 \%$ ) going to the IHX to drive the hydrogen production process, while the majority of the flow is delivered to the power conversion system for electrical power production. 
In these designs, both the hydrogen production process and the power conversion system receive the highest possible temperature fluid.

The three design configurations recommended by Davis et al. are shown in Figures 1, 2 and 3 below. The nomenclature used to define the heat exchangers in these figures is:

- IHX - The first heat exchanger downstream of the NGNP

- PHX - The heat exchanger that connects the intermediate heat transport loop to the hydrogen production plant (in reality this could be multiple heat exchangers)

- SHX - The heat exchanger that, if present, is located between the IHX and the $\mathrm{PHX}$, and is referred to as the secondary heat exchanger (SHX).

The basis for the selection of these three configurations is explained in some detail in Davis et al., 2005. In brief, the direct cycle parallel IHX configuration shown in Figure 1 produces the smallest heat exchanger design and highest overall electrical power production efficiency for the NGNP. The direct cycle configuration in Figure 2 resembles that in Figure 1, but includes a tertiary loop for added separation between the NGNP and the hydrogen production process. While this configuration also results in a small IHX design, the added separation comes at the expense of lower hydrogen production efficiencies. Finally, although the indirect electric power conversion cycle shown in Figure 3 requires the largest IHX design (since it must transfer the full $600 \mathrm{MW}$ of reactor thermal power to the power conversion system and hydrogen production process), the added separation between the NGNP reactor and hydrogen production plant provided by this design may be an added operational benefit.

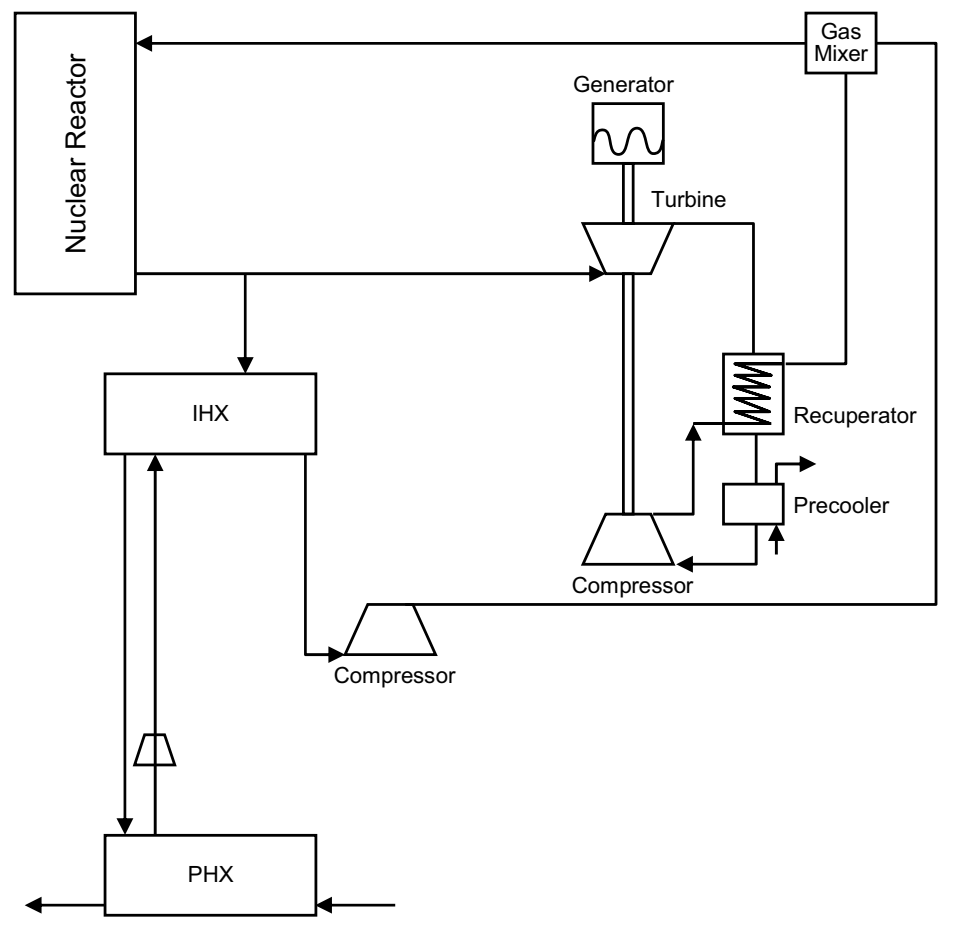

Figure 1. Configuration 1 (direct electrical cycle and a parallel IHX) 


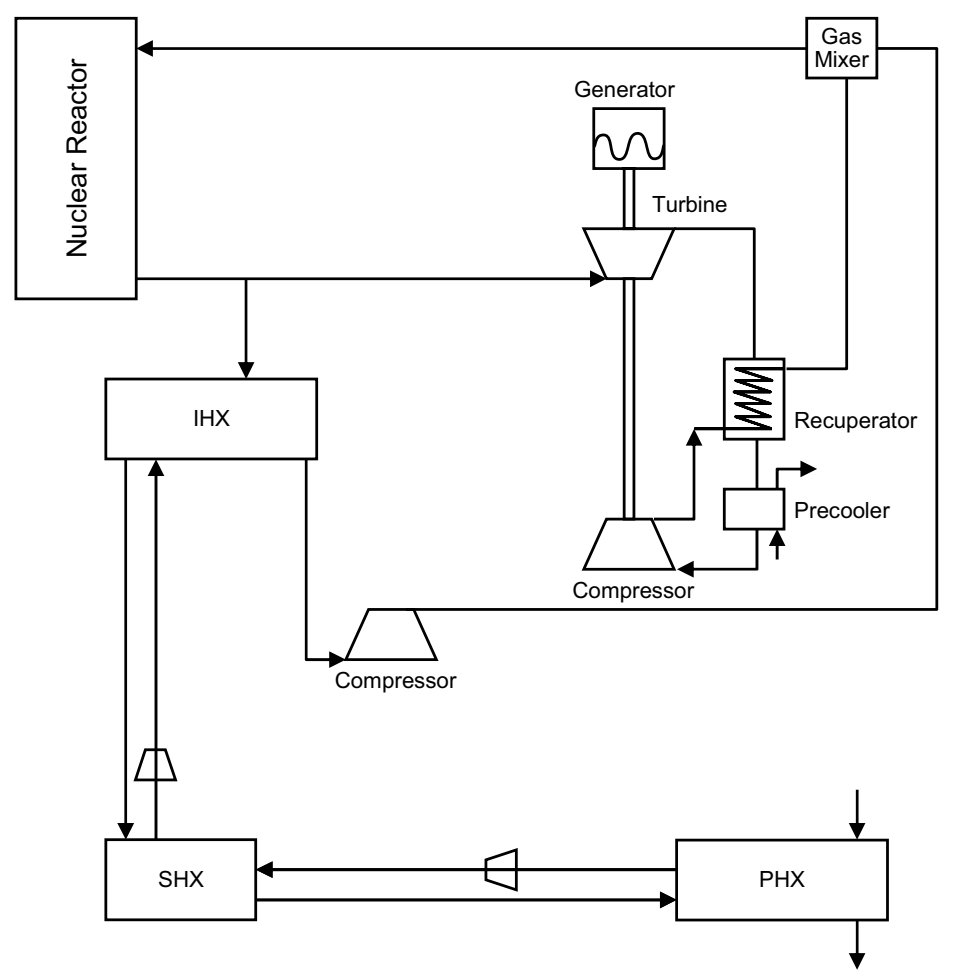

Figure 2. Configuration 2 (direct electrical cycle, parallel IHX, and SHX).

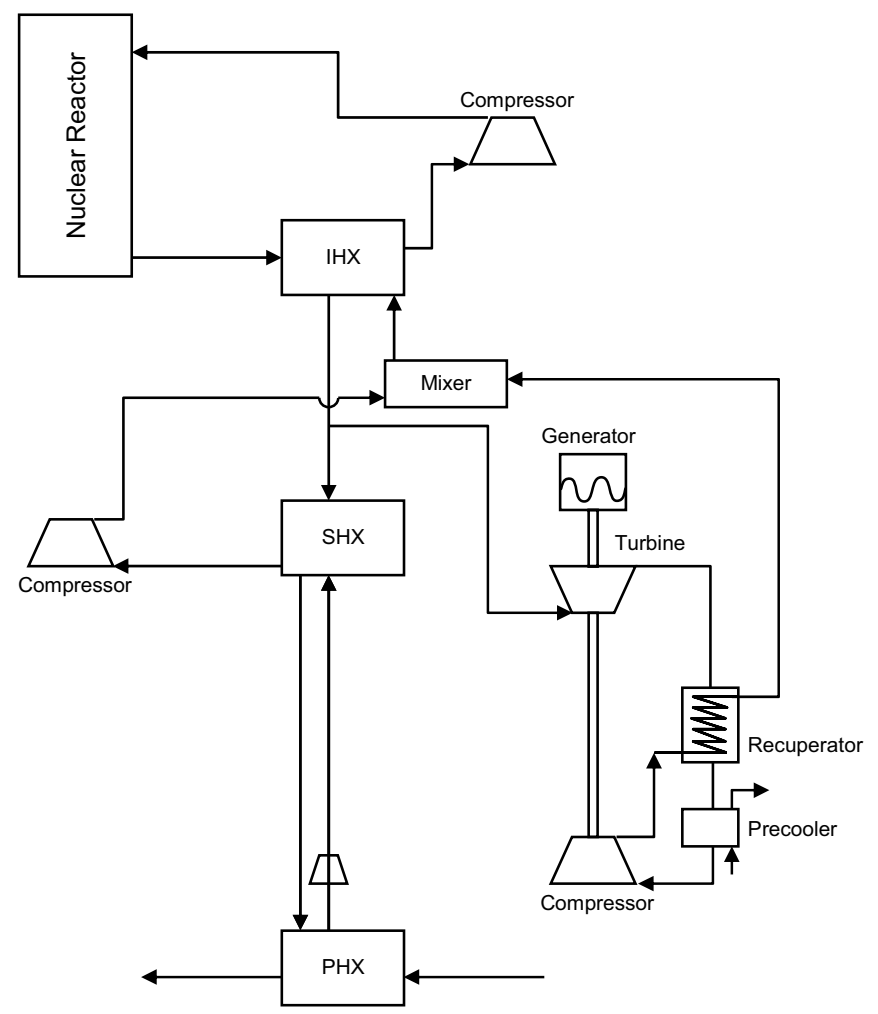

Figure 3. Configuration 3 (indirect electrical cycle and a parallel SHX). 


\section{IHX DESIGN CONSIDERATIONS}

The IHX design will be influenced by a number of interrelated considerations including (1) the required separation distance between the NGNP and the hydrogen production plant, (2) the heat losses from the intermediate loop piping to the surrounding environment, (3) the operating pressure and working fluid (helium or molten salt) in the intermediate loop, and (4) the desired efficiency of the hydrogen production process.

The required separation distance between the NGNP reactor and hydrogen production plant will affect the intermediate loop piping sizes since the allowable pressure drop will determine the diameter of the hot and cold leg pipes. The separation distance also influences piping heat losses to the environment (which were evaluated by Lillo, et al., 2005) and the intermediate loop pumping requirements. Depending on the intermediate loop working fluid (helium or molten salt), the intermediate loop pumping power requirements will have some influence on the overall NGNP cycle efficiency, but given the smaller fluid flow rates in the intermediate loop compared to the primary system, this affect is expected to be small.

The operating pressure of the intermediate loop will probably represent the biggest challenge since the design of the intermediate loop piping and the design of the IHX present conflicting requirements. In previous analyses, Davis et al., 2005 recommended a maximum intermediate loop fluid pressure of $2 \mathrm{MPa}$ to ensure reasonable intermediate loop pipe wall thicknesses. In contrast, Lillo et al., 2005 recommended a minimum intermediate loop fluid pressure of $3 \mathrm{MPa}$, based on analyses they performed for a Printed Circuit Heat Exchanger (PCHE) design for the IHX. Given the information available at the time on the SI process, the conclusions of both reports are valid. However, as discussed later, changes to the SI process being considered by General Atomics (General Atomics, 2006) may make a higher pressure intermediate loop design more attractive.

The following sections describe the evaluation of IHX design conditions for the three selected intermediate loop configurations defined in Section 2. Section 4 describes the methodology used in performing design sensitivity studies. Section 5 summarizes the results of these sensitivity analyses, and Section 6 presents the conclusions of this work.

\section{ANALYSIS METHOD}

The HYSYS process modeling software (Aspen Technology, 2005) was used to perform analyses to define operating conditions for the IHX. Information used to model the intermediate and tertiary loops for the different designs was obtained from Davis et al., 2005, Lillo et al., 2005, Brown et al., 2003, and discussions with General Atomics (General Atomics, 2006). The intermediate loop heat losses used in these evaluations were obtained from Lillo, et al., and the assumed system and component pressure drops are based on the recommendations of Davis et al., 2005. For their analyses, Davis et al. assumed a pressure drop of $50 \mathrm{kPa}$ for all heat exchanger components. Davis, et al. also assumed a pressure drop of $50 \mathrm{kPa}$ in each leg of the intermediate and/or tertiary loop hot and cold leg pipes. These values seem reasonable since, for the General Atomics Modular Helium Reactor (MHR) plant design, pressure drops across the 
core and other major components are in the range of $30 \mathrm{kPa}$ to $70 \mathrm{kPa}$, and appear to be acceptable from a system performance point of view.

Depending on the fluid conditions in the intermediate and tertiary loops, the desired pressure drop (in this case $50 \mathrm{kPa}$ ) will determine the required hot and cold leg pipe diameters. By defining an acceptable pressure drop in the hot and cold legs of the intermediate and/or tertiary loops, the primary effect on system performance is the required pumping power to circulate the intermediate and/or tertiary loop working fluids. This pumping power is in turn affected by the choice of working fluid (helium or molten salt) and fluid conditions (temperature and pressure). However, since only $50 \mathrm{MW}$ of thermal power will be used to produce hydrogen in the NGNP, the intermediate and tertiary loop flow rates and pumping requirements are expected to be small in comparison to the NGNP primary system flow rates and pumping requirements. As a result, the intermediate and tertiary loop pumping requirements should not have a significant affect on overall NGNP plant performance. This would not be the case, however, for a large commercial plant used entirely for hydrogen production since the heat transferred to the hydrogen production process and the resulting intermediate and tertiary loop flow rates and pumping requirements would be much larger, and therefore, would have a larger impact on overall system performance.

\section{ANALYSIS RESULTS}

HYSYS analyses were performed for each of the three configurations shown above. For these calculations, the reactor power was assumed to be $600 \mathrm{MWt}$, which could apply to either the prismatic or pebble bed Very High Temperature Reactor (VHTR) designs. The core $\Delta \mathrm{T}$ in all of the calculations discussed below was assumed to be $360{ }^{\circ} \mathrm{C}$, since that is currently the core $\Delta \mathrm{T}$ defined by General Atomics for their prismatic core design. Although the core $\Delta \mathrm{T}$ for the pebble bed and other prismatic core designs may be higher, $360{ }^{\circ} \mathrm{C}$ was used in these calculations because it produces the highest primary system flow rates for sizing the IHX designs. For evaluation of system performance, gas turbine and compressor power requirements were calculated by HYSYS assuming adiabatic efficiencies of $90 \%$.

Each of the calculations also assumed an IHX effectiveness of 0.95. This heat exchanger effectiveness represents the actual heat duty divided by the maximum possible heat duty of a heat exchanger, and is defined as:

$$
\varepsilon=\frac{\left(\dot{\mathrm{m}} \mathrm{p}_{\mathrm{p}}\right)_{\mathrm{h}}\left(\mathrm{T}_{\mathrm{h} \mathrm{in}}-\mathrm{T}_{\mathrm{h} \mathrm{out}}\right)}{\left(\dot{\mathrm{m}} \mathrm{c}_{\mathrm{p}}\right)_{\min }\left(\mathrm{T}_{\mathrm{h} \mathrm{in}}-\mathrm{T}_{\mathrm{c} \mathrm{in}}\right)},
$$

where $\dot{m}$ is the mass flow rate, $c_{p}$ is the specific heat capacity at constant pressure, and $\mathrm{T}$ is the fluid temperature at the inlet and outlet of the hot and cold sides of the heat exchanger.

The design of the IHX has not been decided, but could be either a printed circuit or countercurrent tube and shell design. However, regardless of the heat exchanger design selected, a heat exchanger effectiveness of 0.95 should provide reasonable heat transfer without imposing excessively large or costly heat exchanger design requirements. 
Finally, for those cases involving helium as the intermediate loop working fluid, it was decided to maintain the same flow rate per unit power in the intermediate loop as in the primary loop. Based on discussions with General Atomics (General Atomics, 2006), this approach should ensure adequate temperature helium is available for the SI heat addition processes downstream of the Sulfur Iodine decomposition heat exchanger. Therefore, for $50 \mathrm{MW}$ of heat transferred to the SI process, the required intermediate loop flow rate $\left(\mathrm{M}_{\text {int. loop }}\right)$ is:

$\mathrm{M}_{\text {int. loop }}=320 \mathrm{~kg} / \mathrm{s} \times(50 \mathrm{MW} / 600 \mathrm{MW})=26.7 \mathrm{~kg} / \mathrm{s}($ helium$)$

\subsection{Configuration 1 (direct electrical cycle and a parallel IHX)}

The HYSYS model for Configuration 1 is shown in Figure 4. The portion of the model on the right represents a direct helium recuperated brayton cycle with intercooling between high and low pressure compressors. After leaving the reactor (top) the flow from the reactor is split with about $10 \%$ of the flow passing through the IHX where its heat is transferred to the intermediate loop. The flow is then compressed and returned to the primary loop flow at the reactor inlet.

As shown in Figure 4, the intermediate loop connects to the secondary side of the IHX. It consists of a hot and cold leg, an intermediate loop compressor, and one or more process heat exchangers. These process heat exchangers provide the heat to drive the SI thermochemical hydrogen production process.

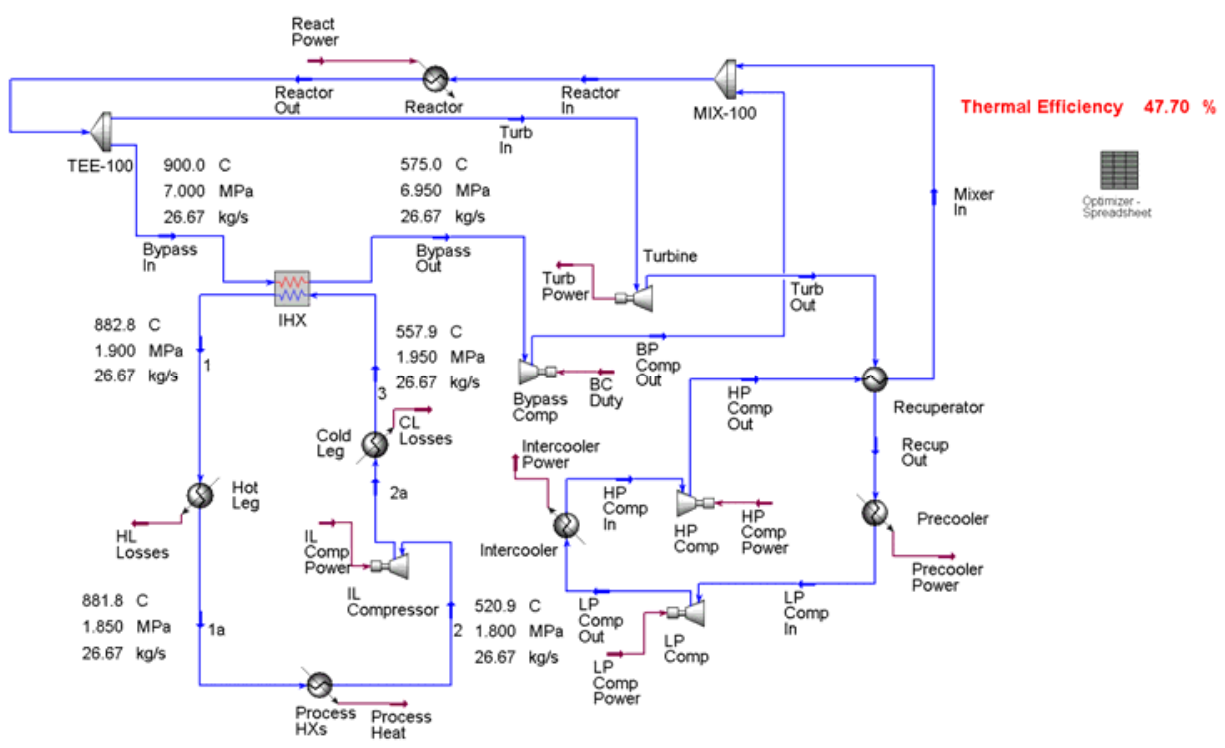

Figure 4. HYSYS model of Configuration 1 (direct electical cycle and a parallel IHX)

The HYSYS model in Figure 4 represents the base case with a reactor outlet temperature of 900 ${ }^{\circ} \mathrm{C}$. The intermediate loop fluid in this case was assumed to be helium at a pressure of $2 \mathrm{MPa}$. Heat losses for this calculation were based on the results of Lillo et al., assuming a 90-m separation distance between the reactor system and the hydrogen production plant. The total of the intermediate loop piping heat losses for this configuration was calculated by Lillo, et al., to be $0.26 \mathrm{MWt}$, and is distribution with approximately $54 \%$ lost from the hot leg and $46 \%$ lost from the cold leg. 
To determine the affect of reactor outlet temperatures on IHX operating conditions, additional HYSYS calculations were also performed for reactor outlet temperatures of $850^{\circ} \mathrm{C}$ and $950^{\circ} \mathrm{C}$. The results of the evaluation of the different reactor outlet temperatures are summarized in Table 1. In the table, the hot side of the IHX is the reactor side and the cold side of the IHX is the intermediate loop side.

Table 1. HYSYS results for Configuration 1 with reactor outlet temperatures of $850{ }^{\circ} \mathrm{C}, 900{ }^{\circ} \mathrm{C}$ and $950{ }^{\circ} \mathrm{C}$.

\begin{tabular}{|l|c|c|c|}
\hline Reactor outlet temperature, ${ }^{\circ} \mathrm{C}$ & 850 & $\begin{array}{c}900 \\
\text { (Base Case) }\end{array}$ & 950 \\
\hline Hot side IHX inlet press., MPa & 7.0 & 7.0 & 7.0 \\
\hline Hot side IHX Outlet Press., MPa & 6.95 & 6.95 & 6.95 \\
\hline Hot side mass flow, kg/s & 26.67 & 26.67 & 26.67 \\
\hline Hot side inlet temp., ${ }^{\circ} \mathrm{C}$ & 850 & 900 & 950 \\
\hline Hot side outlet temp., ${ }^{\circ} \mathrm{C}$ & 523 & 575 & 628 \\
\hline Cold side inlet press., MPa & 1.95 & 1.95 & 1.95 \\
\hline Cold side outlet press., MPa & 1.90 & 1.90 & 1.90 \\
\hline Cold side mass flow, kg/s & 26.67 & 26.67 & 26.67 \\
\hline Cold side inlet temp., ${ }^{\circ} \mathrm{C}$ & 505 & 558 & 611 \\
\hline Cold side outlet temp., ${ }^{\circ} \mathrm{C}$ & 833 & 883 & 933 \\
\hline
\end{tabular}

The reactor outlet temperature primarily influences the overall electric power conversion cycle efficiency and the peak intermediate loop temperature at which heat is delivered to the hydrogen production process. The peak temperature at which heat is delivered to the hydrogen production process in turn determines the hydrogen production plant efficiency. Table 2 summarizes these results for the different reactor outlet temperatures.

The electric power conversion efficiency, $\eta_{\mathrm{PCU}}$ shown in Table 2 is calculated as:

$\eta_{\mathrm{PCU}}=\frac{\text { Electric power output }}{\text { Reactor thermal power }-\mathrm{H}_{2} \text { process power }}=\frac{\Sigma \mathrm{W}_{\mathrm{T}}-\Sigma \mathrm{W}_{\mathrm{C}}-\mathrm{W}_{\mathrm{S}}-\Sigma \mathrm{W}_{\mathrm{CIR}}}{\mathrm{Q}_{\mathrm{th}}-\mathrm{Q}_{\mathrm{H} 2}}$,

where $\Sigma \mathrm{W}_{\mathrm{T}}$ is the total turbine workload, $\Sigma \mathrm{W}_{\mathrm{C}}$ is the total compressor workload, $\mathrm{W}_{\mathrm{S}}$ is the plant stationary load (neglected for these analyses), $\Sigma \mathrm{W}_{\mathrm{CIR}}$ is the circulator workload in the primary, intermediate, and, if present, tertiary loops, $\mathrm{Q}_{\mathrm{th}}$ is the reactor thermal power, and $\mathrm{Q}_{\mathrm{H} 2}$ is the power supplied through the PHX to the hydrogen generating plant.

The peak helium temperature at which heat is delivered to the hydrogen production process was calculated by HYSYS. The hydrogen production efficiency was estimated based on information from Brown, et al., 2003 giving hydrogen production efficiency as a function of the maximum temperature of the sulfur iodine decomposition process. Based on a review of ASPEN process flow sheets contained in Brown, et al., the minimum approach temperature between the helium in the intermediate loop and the sulfuric acid decomposition temperature appears to be between $20^{\circ} \mathrm{C}$ and $25^{\circ} \mathrm{C}$. Therefore, $25^{\circ} \mathrm{C}$ was subtracted from the peak helium delivery temperature to the process heat exchanger to estimate the hydrogen production efficiencies. 
Table 2. System conditions as a function of reactor outlet temperature for Configuration 1.

\begin{tabular}{|l|c|c|c|}
\hline $\begin{array}{l}\text { Reactor Outlet } \\
\text { Temperature, }{ }^{\circ} \mathrm{C}\end{array}$ & 850 & 900 & 950 \\
\hline $\begin{array}{l}\text { Electric Power } \\
\text { Conversion } \\
\text { Efficiency, \% }\end{array}$ & 44.3 & 47.7 & 51.4 \\
\hline $\begin{array}{l}\text { Helium temp. to } \\
\text { Process HX, }{ }^{\circ} \mathrm{C}\end{array}$ & 832 & 882 & 932 \\
\hline $\begin{array}{l}\text { H2 Prod. Efficiency } \\
\text { (estimated), \% }\end{array}$ & 38 & 46 & 50 \\
\hline
\end{tabular}

As expected, all three parameters in Table 3 increase with increased reactor outlet temperature. Assuming a minimum hydrogen production efficiency of $40 \%$ would be desirable for demonstrating hydrogen production processes in the NGNP, the results in Table 2 (last row), indicate that it is probably not feasible to achieve the desired hydrogen produce rates at a reactor outlet temperature of $850^{\circ} \mathrm{C}$.

Since heat losses from the intermediate loop piping can also affect hydrogen production rates, heat loss sensitivity calculations were performed for the base case conditions in Table 1 with a reactor outlet temperature of $900{ }^{\circ} \mathrm{C}$. The heat losses were based on results from Lillo et al., 2005 assuming separate hot and cold leg pipes and an intermediate loop helium pressure of 2 $\mathrm{MPa}$. The affect of these heat loss sensitivity calculations on IHX operating conditions are summarized in Table 3. The total intermediate loop piping heat loss for Case 1 (base case) was $0.26 \mathrm{MW}$ assuming 90 meter hot and cold leg pipe lengths. The total heat loss for Case 2 was $1.82 \mathrm{MW}$ assuming 500 meter pipe lengths. For both cases, the distribution of the total heat losses was apportioned with $54 \%$ allocated to the hot leg and $46 \%$ allocated to the cold leg.

Table 3. HYSYS results for Configuration 1 with variable intermediate loop heat losses.

\begin{tabular}{|l|c|c|}
\hline & $\begin{array}{c}\text { Case 1 } \\
90 \text {-m pipe } \\
\text { lengths }\end{array}$ & $\begin{array}{c}\text { Case 2 } \\
\text { 500-m pipe } \\
\text { lengths }\end{array}$ \\
\hline IHX duty, MW & 45.0 & 46.6 \\
\hline Hot side IHX Inlet Press., MPa & 7.0 & 7.0 \\
\hline Hot side IHX Outlet Press., MPa & 6.95 & 6.95 \\
\hline Hot side mass flow, kg/s & 26.67 & 26.67 \\
\hline Hot side inlet temp., ${ }^{\circ} \mathrm{C}$ & 900 & 900 \\
\hline Hot side outlet temp., ${ }^{\circ} \mathrm{C}$ & 575 & 564 \\
\hline Cold side inlet press., MPa & 1.95 & 1.95 \\
\hline Cold side outlet press., $\mathrm{MPa}$ & 1.90 & 1.90 \\
\hline Cold side mass flow, kg/s & 26.67 & 26.67 \\
\hline Cold side inlet temp., ${ }^{\circ} \mathrm{C}$ & 558 & 546 \\
\hline Cold side outlet temp., ${ }^{\circ} \mathrm{C}$ & 883 & 882 \\
\hline Temperature to Process $\mathrm{HX},{ }^{\circ} \mathrm{C}$ & 882 & 875 \\
\hline H2 Prod. Efficiency $(\mathrm{est}),. \%$ & 46 & 45 \\
\hline
\end{tabular}


The results of Table 3 show that the intermediate loop heat losses have a relatively small impact on the IHX heat duty (first row) and the estimated efficiency of the hydrogen production process (last row). For Case 1 (90-m separation distance) and Case 2 (500-m separation distance) the IHX heat duty is less than the $50 \mathrm{MWt}$ transferred to the hydrogen production process because of the heat of compression added to the intermediate loop helium by the intermediate loop compressor. As the intermediate loop heat losses increase, the required IHX duty in turn increases.

Based on the results of Table 3, for an intermediate loop operating pressure of $2.0 \mathrm{MPa}$, heat losses from the intermediate loop are not expected to be a major concern, and in any event, will not exceed the heat of compression added to the intermediate loop fluid by the intermediate loop compressor. In fact, the heat of compression added to the intermediate loop helium at $2 \mathrm{MPa}$ is about 3 times the maximum pipe heat losses calculated by Lillo, et al. for a 500-m separation distance between the reactor system and the hydrogen production plant.

Sensitivity calculations were also performed to evaluate the impact of the intermediate loop operating pressure on system performance. Since the pipe diameters for the intermediate loop will change to maintain the desired pressure loss (in this case $50 \mathrm{kPa}$ in each leg), the primary impact of the change in intermediate loop pressure will be on the required intermediate loop pumping power (and the associated compression heating of the helium in the intermediate loop), which will be reduced with increased intermediate loop helium pressure. A decrease in intermediate loop pumping power will also increase the overall cycle efficiency since less electric power will be required to drive the intermediate loop compressor.

The selection of an appropriate intermediate loop pressure is critical because a low intermediate loop pressure will produce a high differential pressure between the primary and intermediate loop sides of the IHX, and a high intermediate loop pressure results in a large differential pressure across the intermediate loop pipe walls. In addition, a high intermediate loop pressure also results in a large differential pressure across the process heat exchange equipment if the SI process operating pressure is low. To reduce the pressure differential between the helium intermediate loop and the process side of the SI process heat exchange equipment, General Atomics (General Atomics, 2006) has increased the SI process pressure from 0.07 MPa (baseline design) to 7.0 MPa. General Atomics' initial evaluations indicate that the increased process operating pressure will not significantly reduce overall hydrogen production efficiencies. When operating at a 7.0 MPa process pressure (equal to the pressure of the primary system), the intermediate loop in the General Atomics design is operated at 7.1 MPa. This intermediate loop operating pressure would significantly reduce the pressure across the IHX and ensure that for a leak or small break in the IHX, the flow direction is from the intermediate loop to the primary system. This flow direction minimizes the potential for contamination from the primary side spreading to the intermediate loop and/or hydrogen production processes. To evaluate the impact of a higher pressure intermediate loop, a calculation was performed for an intermediate loop pressure of $7.1 \mathrm{MPa}$, with a reactor outlet temperature of $900{ }^{\circ} \mathrm{C}$. For this high pressure case, a total intermediate loop heat loss of $0.22 \mathrm{MW}$ was assumed with $54 \%$ of the total heat loss allocated to the intermediate loop hot leg and $46 \%$ allocated to the intermediate loop cold leg (Lillo, et al., 2005). The results of this high pressure calculation are compared in Table 4 with the results of the earlier base case calculation at $2 \mathrm{MPa}$. 
Table 4. HYSYS results for Configuration 1 with variable intermediate loop pressures.

\begin{tabular}{|l|c|c|}
\hline & $\begin{array}{c}\text { Intermediate Loop Press }= \\
2 \mathrm{MPa} \text { (base case) }\end{array}$ & $\begin{array}{c}\text { Intermediate Loop Press = } \\
7.1 \mathrm{MPa}\end{array}$ \\
\hline IHX duty, MW & 45.0 & 48.8 \\
\hline Hot side IHX Inlet Press., MPa & 7.0 & 7.0 \\
\hline $\begin{array}{l}\text { Hot side IHX Outlet Press., } \\
\text { MPa }\end{array}$ & 6.95 & 6.95 \\
\hline Hot side mass flow, $\mathrm{kg} / \mathrm{s}$ & 26.67 & 26.67 \\
\hline Hot side inlet temp., ${ }^{\circ} \mathrm{C}$ & 900 & 900 \\
\hline Hot side outlet temp., ${ }^{\circ} \mathrm{C}$ & 575 & 548 \\
\hline Cold side inlet press., $\mathrm{MPa}$ & 1.95 & 7.05 \\
\hline Cold side outlet press., $\mathrm{MPa}$ & 1.90 & 7.0 \\
\hline Cold side mass flow, $\mathrm{kg} / \mathrm{s}$ & 26.67 & 26.67 \\
\hline Cold side inlet temp., ${ }^{\circ} \mathrm{C}$ & 558 & 529 \\
\hline Cold side outlet temp., ${ }^{\circ} \mathrm{C}$ & 883 & 882 \\
\hline $\begin{array}{l}\text { Helium temperature to process } \\
\text { HX, }{ }^{\circ} \mathrm{C}\end{array}$ & 882 & 881 \\
\hline H2 Prod. Efficiency (est.), $\%$ & & 46 \\
\hline
\end{tabular}

The results summarized in Table 4 indicate that the primary difference in system operating conditions for an intermediate loop operating pressures of $7.1 \mathrm{MPa}$ and $2.0 \mathrm{MPa}$ is the result of the lower intermediate loop pumping requirements at the higher intermediate loop fluid pressure. With less heat of compression added to the intermediate loop fluid at high pressure, the intermediate loop IHX (cold) inlet temperature is lower, as is the IHX primary side (hot) outlet temperature. Because of the reduced heat of compression added to the intermediate loop fluid in the high pressure case, the IHX duty (row 2) is increased. However, the helium temperatures to the process heat exchanger (second to last row) are nearly the same, and there is no difference in the estimated hydrogen production efficiencies (last row). Although the above results do not show significant differences in overall hydrogen production efficiencies with changes in intermediate loop pressure, the obvious advantage of operating the intermediate loop at $7.1 \mathrm{MPa}$, is the low pressure differential between the primary and intermediate loop sides of the IHX and the resulting lower induced stresses.

Because of its higher density and lower pumping requirements at low fluid pressures, a molten salt (Flinak) was also evaluated as the potential working fluid in the intermediate loop, and compared with the results above. The operating pressure of the molten salt was assumed to be 2.0 MPa, and a total heat loss of $0.13 \mathrm{MW}$, corresponding to a separation distance of 90 meters (Lillo, et al., 2005), was used.

Figure 5 shows the HYSYS model for Configuration 1 with Flinak as the intermediate loop working fluid. Since Flinak is a liquid at these temperatures, the intermediate loop compressor is replaced with a pump operating at $75 \%$ adiabatic efficiency. 


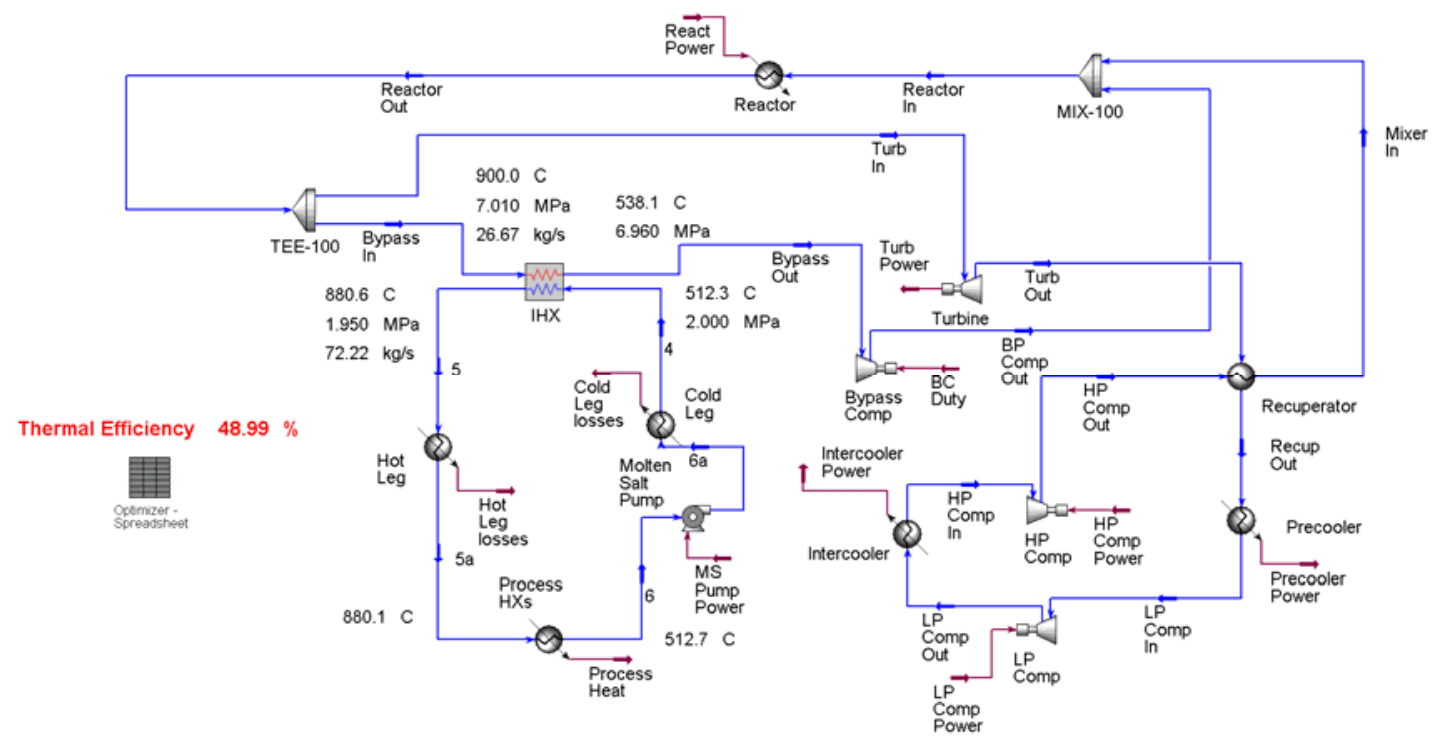

Figure 5. HYSYS model of Configuration 1 with Flinak as intermediate loop working fluid.

The overall affect of the different working fluids and pressures on IHX heat duty, pumping power requirements and overall NGNP cycle efficiency are summarized in Table 5.

Table 5. HYSYS calculated system conditions for variable intermediate loop pressure and working fluid.

\begin{tabular}{|l|c|c|c|}
\hline Working fluid & Helium & Helium & Flinak \\
\hline $\begin{array}{l}\text { Intermediate loop } \\
\text { pressure, MPa }\end{array}$ & 2.0 & 7.1 & 2.0 \\
\hline $\begin{array}{l}\text { Int. loop } \\
\text { compressor/pump } \\
\text { power, kW }\end{array}$ & 5257 & 1417 & 11.31 \\
\hline IHX heat duty, MW & 45 & 48.8 & 50.1 \\
\hline $\begin{array}{l}\text { Overall electric } \\
\text { power efficiency, \% }\end{array}$ & 47.7 & 48.4 & 49.0 \\
\hline
\end{tabular}

Table 5 show a significant decrease in intermediate loop pumping power when Flinak is used as the working fluid (row 3). The lower pumping power also results in a small increase in the IHX heat duty (second to last row) since less heat in the form of pump work is added to the Flinak, and therefore, more heat must be transferred from the primary system fluid across the IHX to the intermediate loop fluid. Although the relative differences in pumping requirements for the three cases in Table 5 appear large, these pumping losses are small compared to other losses in the system (because of the low fluid flow rates in the intermediate loop). Therefore, the overall affect of different fluids or different operating pressures on overall NGNP electric power production efficiency is small. These results indicate that the overall system performance will not be significantly influenced by the choice of intermediate loop pressure or working fluid. As noted earlier, a higher intermediate loop pressure will reduce the pressure difference and resulting stresses across the IHX, which is a critical design consideration for the IHX, particularly for reactor outlet temperatures approaching $950{ }^{\circ} \mathrm{C}$. The opposing design 
consideration is that the intermediate loop piping thicknesses would have to be increased to accommodate the higher intermediate loop design pressure.

\subsection{Configuration 2 (direct electrical cycle, parallel IHX, and SHX)}

Configuration 2 is similar to Configuration 1 but includes a tertiary loop for added separation between the NGNP reactor and the hydrogen production plant. Figure 6 shows the HYSYS model used for this configuration.

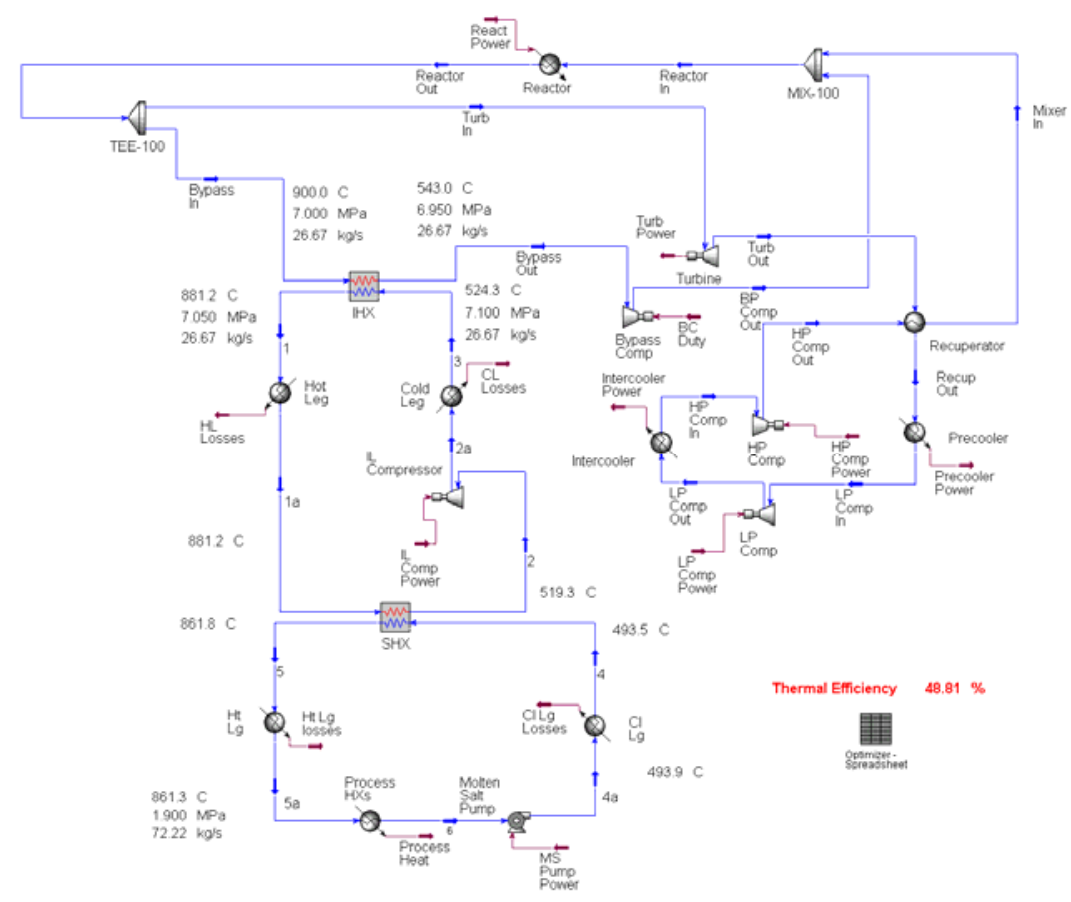

Figure 6. HYSYS model of Configuration 2 (direct electrical cycle, parallel IHX, and SHX).

For this model, the intermediate loop was assumed to be hydrogen at high pressure (7.1 MPa). The tertiary loop was assumed to provide the separation distance between the reactor and the hydrogen plant. Therefore, the high pressure intermediate loop was assumed to be short enough that piping heat losses and pressure drops could be ignored. In this case, the tertiary loop working fluid was assumed to be molten salt (Flinak) to minimize the hot and cold leg pipe diameters and the pumping requirements for this loop. Since the addition of the tertiary loop will not significantly affect the IHX operating conditions calculated for Configuration 1, previous sensitivity calculations were not repeated. However, because of the additional temperature drop between the reactor outlet and the process heat exchanger, calculations were performed at reactor outlet temperatures of $900{ }^{\circ} \mathrm{C}$ and $950{ }^{\circ} \mathrm{C}$ to determine the impact of the tertiary loop on the estimated hydrogen production efficiencies ${ }^{\mathrm{a}}$. For these calculations the tertiary loop (Flinak)

\footnotetext{
${ }^{\mathrm{a}}$ The HYSYS calculation at a reactor outlet temperature of $850{ }^{\circ} \mathrm{C}$ is not reported because the molten salt temperature at the IHX inlet dropped below the freezing temperature of Flinak.
} 
was operated at $2 \mathrm{MPa}$. The total heat losses for the tertiary loop were again assumed to be 0.13 MPa (Lillo, et al.). The results of these analyses are summarized in Table 6.

Table 6. HYSYS results for Configuration 2 with variable reactor outlet temperature.

\begin{tabular}{|l|c|c|}
\hline $\begin{array}{l}\text { Reactor Outlet } \\
\text { Temperature, }{ }^{\circ} \mathrm{C}\end{array}$ & 900 & 950 \\
\hline IHX duty, MW & 49.3 & 49.4 \\
\hline $\begin{array}{l}\text { Hot side IHX Inlet Press., } \\
\mathrm{MPa}\end{array}$ & 7.0 & 7.0 \\
\hline $\begin{array}{l}\text { Hot side IHX Outlet Press., } \\
\mathrm{MPa}\end{array}$ & 6.95 & 6.95 \\
\hline Hot side mass flow, $\mathrm{kg} / \mathrm{s}$ & 26.67 & 26.67 \\
\hline Hot side inlet temp., ${ }^{\circ} \mathrm{C}$ & 900 & 953 \\
\hline Hot side outlet temp., ${ }^{\circ} \mathrm{C}$ & 543 & 593 \\
\hline Cold side inlet press., MPa & 7.1 & 7.1 \\
\hline Cold side outlet press., MPa & 7.05 & 7.05 \\
\hline Cold side mass flow, $\mathrm{kg} / \mathrm{s}$ & 26.67 & 26.67 \\
\hline Cold side inlet temp., ${ }^{\circ} \mathrm{C}$ & 524 & 575 \\
\hline Cold side outlet temp., ${ }^{\circ} \mathrm{C}$ & 881 & 931 \\
\hline $\begin{array}{l}\text { Temperature to Process } \mathrm{HX}, \\
{ }^{\circ} \mathrm{C}\end{array}$ & 861 & 911 \\
\hline $\begin{array}{l}\text { H2 Prod. Efficiency (est.), } \\
\%\end{array}$ & 43 & 49 \\
\hline Cycle Efficiency, $\%$ & & \\
\hline
\end{tabular}

As observed in Table 6, the added separation provided by Configuration 2 comes at the expense of a larger temperature drop and lower hydrogen production efficiencies (second to last row of Table 6) when compared to the Configuration 1 efficiencies in Table 2 (last row). These results indicate that the reactor outlet temperature for Configuration 2 will have to be increased by approximately $20^{\circ} \mathrm{C}$ to achieve the equivalent hydrogen production efficiencies of Configuration 1. Therefore, the tradeoff is between the safety related advantages associated with the added separation provided by Configuration 2 and the materials and performance issues associated with operating at higher reactor outlet temperatures to achieve acceptable hydrogen production efficiencies.

\subsection{Configuration 3 (indirect electrical cycle and a parallel SHX)}

Configuration 3 represents an indirect electrical cycle with a parallel SHX. In this case all of the heat from the primary system is transferred through the IHX to the secondary loop where the flow is split between the power conversion system and the hydrogen production system. The HYSYS model for this configuration is shown in Figure 7. 


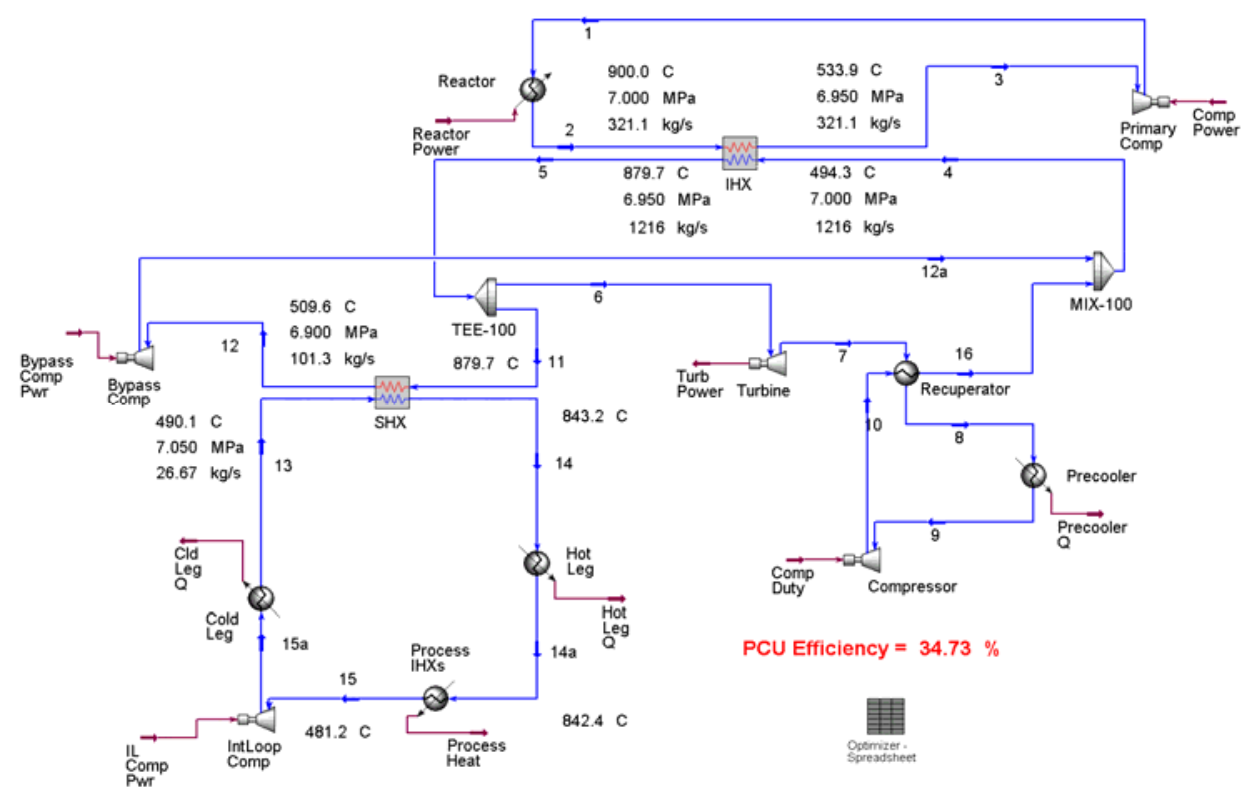

Figure 7. HYSYS model of Configuration 3 (indirect electrical cycle and a parallel SHX).

Since detailed design information was not available for the indirect power conversion cycle, a simple recuperated brayton cycle with a single compressor and no intercooling was assumed. The working fluid for the power conversion system was assumed to be a gas mixture consisting of $80 \%$ nitrogen and $20 \%$ helium. This gas mixture was chosen to allow the use of more conventional turbine designs. The gas mixture to the turbine inlet was assumed to be at 6.95 $\mathrm{MPa}$. The tertiary loop working fluid in this case was helium at a pressure of $7.1 \mathrm{MPa}$ at the tertiary loop compressor outlet.

Results of calculations performed for this design at reactor outlet temperatures of $850{ }^{\circ} \mathrm{C}$, $900{ }^{\circ} \mathrm{C}$ and $950^{\circ} \mathrm{C}$ are shown in Table 7.

Table 7. HYSYS results for Configuration 3 with variable reactor outlet temperature.

\begin{tabular}{|l|c|c|c|}
\hline Reactor outlet temperature, ${ }^{\circ} \mathrm{C}$ & 850 & 900 & 950 \\
\hline IHX heat duty, MWt & 610 & 610 & 611 \\
\hline $\begin{array}{l}\text { Primary (hot) side IHX Inlet Press., } \\
\mathrm{MPa}\end{array}$ & 7.0 & 7.0 & 7.0 \\
\hline Primary side IHX Outlet Press., MPa & 6.95 & 6.95 & 6.95 \\
\hline Primary (hot) side mass flow, kg/s & 321 & 321 & 321 \\
\hline Primary side inlet temp., ${ }^{\circ} \mathrm{C}$ & 850 & 900 & 950 \\
\hline Primary side outlet temp., ${ }^{\circ} \mathrm{C}$ & 484 & 534 & 584 \\
\hline $\begin{array}{l}\text { Secondary side (cold) inlet press., } \\
\text { MPa }\end{array}$ & 7.0 & 7.0 & 7.0 \\
\hline Secondary side outlet press., MPa & 6.95 & 6.95 & 6.95 \\
\hline Secondary (cold) side mass flow, kg/s & 1216 & 1,216 & 1,216 \\
\hline Secondary side inlet temp., ${ }^{\circ} \mathrm{C}$ & 443 & 494 & 546 \\
\hline Secondary side outlet temp., ${ }^{\circ} \mathrm{C}$ & 830 & 880 & 930 \\
\hline
\end{tabular}


The design of the IHX for this configuration is much larger than the other configurations because all of the primary system heat is transferred across the IHX. The IHX heat duties (row 2) exceed the reactor thermal power because the heat of compression from the primary side compressor is also removed from the primary side through the IHX. In addition, the lower heat capacity of the power conversion system gas mixture requires about 4 times as much flow to transfer the equivalent amount of heat as the helium on the primary side.

As discussed earlier, the reactor outlet temperature primarily influences the overall electric power conversion cycle efficiency and the peak intermediate loop temperature at which heat is delivered to the hydrogen production process. The peak temperature at which heat is delivered to the hydrogen production process in turn determines the hydrogen production plant efficiency. Table 8 summarizes these results for the different reactor outlet temperatures. As in the previous results, the electric power conversion efficiency and the peak helium temperature at which heat is delivered to the hydrogen production process were calculated using HYSYS. The hydrogen production efficiency was estimated by subtracting $25^{\circ} \mathrm{C}$ from the peak helium delivery temperature to the process heat exchanger.

Table 8. System conditions for Configuration 3 with variable reactor outlet temperature.

\begin{tabular}{|l|c|c|c|}
\hline $\begin{array}{l}\text { Reactor outlet } \\
\text { temperature, }{ }^{\circ} \mathrm{C}\end{array}$ & 850 & 900 & 950 \\
\hline $\begin{array}{l}\text { Electric Power } \\
\text { Conversion } \\
\text { Efficiency, \% }\end{array}$ & 31.9 & 34.7 & 37.6 \\
\hline $\begin{array}{l}\text { Temperature to } \\
\text { Process HX, }{ }^{\circ} \mathrm{C}\end{array}$ & 791 & 842 & 895 \\
\hline $\begin{array}{l}\text { H2 Prod. Efficiency } \\
\text { (est.), \% }\end{array}$ & 30 & 40 & 47 \\
\hline
\end{tabular}

The calculated power conversion efficiencies (row 2) for the indirect cycle are not directly comparable with the direct power conversion cycle results shown earlier because no attempt to optimize this indirect power conversion cycle was made. However, because of the higher pumping requirements, the overall efficiencies of the indirect cycle are expected to be less than for the direct cycle.

Results from this evaluation indicate that the indirect power conversion cycle shown in Figure 3 will provide lower temperature heat to the SI process and therefore result in lower hydrogen production efficiencies than predicted for the direct cycle configuration shown in Figure 1. The added separation between the primary system and the hydrogen production process provided by Configuration 3, however, may have some additional safety and operational advantages compared to Configuration 1. 


\section{CONCLUSIONS}

There are several possible options for the design of the IHX for the NGNP. Based on sensitivity results presented in this report, the following conclusions were drawn.

- Reactor outlet temperatures below $900{ }^{\circ} \mathrm{C}$ will probably not be adequate for demonstrating high efficiency hydrogen production in the NGNP.

- The direct cycle shown in Configuration 1 offers higher overall cycle and hydrogen production efficiencies than does the indirect cycle in Configuration 3.

- There is a hydrogen production penalty associated with using a tertiary loop (Configuration 2), which can only be justified by demonstrated significant safety advantages.

- Intermediate loop heat losses for the NGNP appear to be manageable, and in most cases should be less than the heat of compression added to the working fluid by the intermediate loop compressor.

- The design of the IHX and process heat exchangers, including selection of materials will be considerably simplified if the intermediate loop is operated at high pressure (7.1 $\mathrm{MPa})$. The operation of the intermediate loop at high pressure assumes that the thermochemical process loop can also be operated at high pressure $(7 \mathrm{MPa})$ without significant reductions in hydrogen production efficiencies.

- If operation of the NGNP intermediate loop at low pressures (2 MPa) is required, helium is probably the preferred working fluid since there is not a substantial difference in overall system performance using helium as opposed to a molten salt. (This may not be the case for a commercial plant using all of its power for the production of hydrogen, since intermediate loop pumping requirements will be more significant.)

Based on the above considerations, it is recommended that the design of the IHX be further evaluated for two different configurations, the direct cycle (Configuration 1) and the indirect cycle (Configuration 3).

Table 9 below defines recommended design parameters for the IHX for Configuration 1 at intermediate loop pressures of $2.0 \mathrm{MPa}$ and $7.1 \mathrm{MPa}$, and at reactor outlet temperatures of 900 ${ }^{\circ} \mathrm{C}$ and $950{ }^{\circ} \mathrm{C}$. The IHX conditions in Table 9 were taken from earlier calculations presented in this report, but for added margin assumed a $20 \%$ increase in fluid flow rates and heat delivered to the hydrogen production process $(50$ to $60 \mathrm{MWt}$ ). This results in a $20 \%$ margin in the heat duty of the IHX for these conditions. 
Table 9. Recommended IHX thermal-hydraulic conditions for Configuration 1.

\begin{tabular}{|c|c|c|c|c|}
\hline Configuration 1 & $\begin{array}{l}\text { React outlet }= \\
900{ }^{\circ} \mathrm{C} \\
\text { Int loop press }= \\
2.0 \mathrm{MPa}\end{array}$ & $\begin{array}{l}\text { Reactor outlet }= \\
900{ }^{\circ} \mathrm{C} \\
\text { Int loop press }= \\
7.1 \mathrm{MPa}\end{array}$ & $\begin{array}{l}\text { Reactor outlet }= \\
950{ }^{\circ} \mathrm{C} \\
\text { Int loop press }= \\
2.0 \mathrm{MPa}\end{array}$ & $\begin{array}{l}\text { Reactor outlet }= \\
950{ }^{\circ} \mathrm{C} \\
\text { Int loop press }= \\
7.1 \mathrm{MPa}\end{array}$ \\
\hline $\begin{array}{l}\text { Heat Duty, } \\
\text { MWt }\end{array}$ & 54.0 & 58.6 & 53.6 & 60.5 \\
\hline $\begin{array}{l}\text { Overall UA, } \\
\mathrm{MW} /{ }^{\circ} \mathrm{C}\end{array}$ & 3.14 & 3.15 & 3.15 & 3.15 \\
\hline $\mathrm{LMTD},{ }^{\circ} \mathrm{C}$ & 17.2 & 18.6 & 17.0 & 19.2 \\
\hline $\begin{array}{l}\text { Hot side IHX } \\
\text { Inlet Press., } \\
\mathrm{MPa}\end{array}$ & 7.0 & 7.0 & 7.0 & 7.0 \\
\hline $\begin{array}{l}\text { Hot side IHX } \\
\text { Outlet Press., } \\
\mathrm{MPa}\end{array}$ & 6.95 & 6.95 & 6.95 & 6.95 \\
\hline $\begin{array}{l}\text { Hot side mass } \\
\text { flow, } \mathrm{kg} / \mathrm{s}\end{array}$ & 32.0 & 32.0 & 32.0 & 32.0 \\
\hline $\begin{array}{l}\text { Hot side inlet } \\
\text { temp., }{ }^{\circ} \mathrm{C}\end{array}$ & 900 & 900 & 950 & 950 \\
\hline $\begin{array}{l}\text { Hot side outlet } \\
\text { temp., }{ }^{\circ} \mathrm{C}\end{array}$ & 575 & 547 & 628 & 586 \\
\hline $\begin{array}{l}\text { Cold side inlet } \\
\text { press., } \mathrm{MPa}\end{array}$ & 1.95 & 7.05 & 1.95 & 7.05 \\
\hline $\begin{array}{l}\text { Cold side outlet } \\
\text { press., } \mathrm{MPa}\end{array}$ & 1.90 & 7.0 & 1.90 & 7.0 \\
\hline $\begin{array}{l}\text { Cold side mass } \\
\text { flow, } \mathrm{kg} / \mathrm{s}\end{array}$ & 32.0 & 32.0 & 32.0 & 32.0 \\
\hline $\begin{array}{l}\text { Cold side inlet } \\
\text { temp., }{ }^{\circ} \mathrm{C}\end{array}$ & 558 & 528 & 611 & 566 \\
\hline $\begin{array}{l}\text { Cold side outlet } \\
\text { temp., }{ }^{\circ} \mathrm{C}\end{array}$ & 883 & 881 & 933 & 931 \\
\hline
\end{tabular}

Table 10 defines the recommended design parameters for Configuration 3 assuming the power conversion unit working fluid is a gas mixture of $80 \%$ nitrogen and $20 \%$ helium. For this configuration, the tertiary loop working fluid was assumed to be helium at a pressure of 7.1 MPa. However, molten salt could also be considered for use in the tertiary loop if desired. For added design margin, the results in Table 10 assume an increase of $5 \%$ in reactor power and primary system mass flow rate (ie., to $630 \mathrm{MWt}$ and $336 \mathrm{~kg} / \mathrm{s}$, respectively). In addition, the heat delivered to the hydrogen production process was assumed to increase from 50 to $60 \mathrm{MWt}$. This results in approximately a $5 \%$ margin in the heat exchanger heat duty for the conditions shown in Table 10. 
Table 10. Recommended thermal-hydraulic conditions for Configuration 3.

\begin{tabular}{|l|c|c|}
\hline Configuration 3 & React outlet $=900{ }^{\circ} \mathrm{C}$ & React outlet $=950{ }^{\circ} \mathrm{C}$ \\
\hline Heat Duty, MWt & 640.8 & 641.5 \\
\hline Overall UA, MW $/{ }^{\circ} \mathrm{C}$ & 23.74 & 24.55 \\
\hline LMTD, ${ }^{\circ} \mathrm{C}$ & 27.0 & 26.1 \\
\hline $\begin{array}{l}\text { Hot side IHX Inlet Press., } \\
\mathrm{MPa}\end{array}$ & 7.0 & 7.0 \\
\hline $\begin{array}{l}\text { Hot side IHX Outlet Press., } \\
\mathrm{MPa}\end{array}$ & 6.95 & 6.95 \\
\hline Hot side mass flow, $\mathrm{kg} / \mathrm{s}$ & 336 & 336 \\
\hline Hot side inlet temp., ${ }^{\circ} \mathrm{C}$ & 900 & 950 \\
\hline Hot side outlet temp., ${ }^{\circ} \mathrm{C}$ & 533 & 582 \\
\hline Cold side inlet press., $\mathrm{MPa}$ & 7.0 & 7.0 \\
\hline Cold side outlet press., $\mathrm{MPa}$ & 6.95 & 6.95 \\
\hline Cold side mass flow, $\mathrm{kg} / \mathrm{s}$ & 1,277 & 1,277 \\
\hline Cold side inlet temp., ${ }^{\circ} \mathrm{C}$ & 495 & 546 \\
\hline Cold side outlet temp., ${ }^{\circ} \mathrm{C}$ & 880 & 930 \\
\hline
\end{tabular}




\section{REFERENCES}

Davis, C. B., Oh, C. H., Barner, R. B., Sherman, S. R., and Wilson, D. F., "Thermal-Hydraulic Analyses of Heat Transfer Fluid Requirements and Characteristics for Coupling A Hydrogen Production Plant to a High-Temperature Nuclear Reactor", INL/EXT-05-00453. June 2005.

Lillo, T. M., Williamson, R. L., Reed, T. R., Davis, C. B., and Ginosar, D. M., "Engineering Analysis of Intermediate Loop and Process Heat Exchanger Requirements to Include Configuration Analysis and Material Needs”, INL/EXT-05-00690, September 2005.

General Atomics, Telephone conversations with General Atomics personnel, March 2006.

Aspen Technology, 2005, “HYSYS Process Version 2.2.2”, www.aspentech.com.

Brown, L. C., Besenbruch, G. E., Lentsch, R. D., Schultz, K. R., Funk, J. F., Pickard, P. S., Marshall, A. C., and Showalter, S. K., "High Efficiency Generation of Hydrogen Fuels using Nuclear Power”, GA-A24285, Rev. 1, December 2003. 